\title{
The History of Computer Science and Technology 50 more references...
}

\author{
Camille Akmut
}

November 2, 2019

\begin{abstract}
A project conceived some time ago, and now finally completed. One hundred references to create a thousand more researchers!
\end{abstract}




\section{Primary sources}

Read : open problems.

\section{Writings by computer scientists, technologists}

1. stallman.org

Description a conundrum and vast labyrinth for generations upon generations of historians to come. The site is roughly divided into : news notes (the bulk of it, about 10-20 a day), articles (on free software and other subjects), and more personal writings.

2. gnu.org

Description the GNU project is both a philosophy and an actual, realized system (of inter-related software, or operating system). About 400 package maintainers and thousands of contributors, currently (first-hand source).

3. lists.gnu.org

Description (the many!) mailing lists for this collaborative project.

4. planet.debian.org

Description a "planet" is a collection of blogs, here from Debian's members. Not limited to technological topics. (There was never such a thing as "purely technical"...)

\section{Legal documents}

5. General Data Protection Regulation.

Description A landmark law (a so-called "regulation", in EU legal terminology). In particular art. 17, "The data subject shall have the right to obtain from the controller the erasure of personal data" (where, roughly, "data subject" means the user, and "(data) controller" means a company or any organization/institution).

\section{Monographs}

More open problems, at every turn of a page.

6. Black, Edwin. 2012 [2001]. IBM and the holocaust. Expanded ed.. Dialog Press.

Description Watson must have thought not unlike many of our modern technology CEO's in that June of 1934... He made a "killing" with Dehomag (trans. German Hollerith machines company), all the while managing to turn a blind eye to the great misery and tragedy that was unfolding all around him. (Contemporaneous posters gave its location in Lichterfelde, a district of Berlin to the South.) (Typology : journalist turned historian.)

7. Sandberg, Sheryl and Scovell, Nell. 2013. Lean In. Knopf.

Description central figure and cornerstone text of corporate diversity; a philosophy of false promises, and false premises. ("Purely impure", we called it, a reference to The German Ideology's closing part on Saint Max, Max Stirner. Greed turned into virtue : another solution to what we've 
called the "Galbraith equation", humanity's oldest problem. Saccharine is as close as Sandberg ever came to the lives of average, normal people the brown, false sugar of the poor...)

8. Singer, Peter. 2016. The Most Good You Can Do. Yale University Press.

Description effective altruism, another peculiar philosophy of this epoch; favored by technological circles for good reason. (Singer and McAskill are truly the Bauer Brothers of our days. "The holy family" : Singer and sons... McAskill and brothers...) (Published by a private university, employed by one.) "In its holy zeal against the mass, [effective altruism] pays it the finest compliment." For the average person to make donations is fine, but - listen up, it's not "the most good you can do"! An investment banker or tech CEO, on the other hand, emptying their pockets for change all the while implementing draconian, Dickensian working conditions back at home - now, boy oh boy, that is grand altruism, and must be grand philosophy! Singer and McAskill, let's be clear, are the scum of the earth : the lowest of the lowest of hanging fruits (spoiled, foul and ready to drop); meanwhile they parade themselves around Oxford or Princeton, and these gentlemen and gentlewomen of some education cannot even see through the poverty of their philosophy...

9. Barlow, John. 2018. Mother American Night. Crown Archetype.

Description contemporary Libertarian figure who created a widely adopted and highly influential vision of privacy conceived primarily as defense against the State (i.e. the 'big, bad' government - he had in mind, of course, the federal government of his country, the USA). His essay on cyberspace (opening with the lines "You weary giants of steel...") has never been more outdated, and couldn't be less relevant now.

Barlow, Singer, Sandberg : B.S.S. or B. $S^{2}$

Three cornerstones of currently dominant technology ideology...

10. Snowden, Edward. 2019. Permanent record. Metropolitan Books.

Description choice passages were promptly published in The Intercept ("...the things I think I had meant at the time"), but this does not explain much. Specifically, it doesn't explain the main problem, which is the political evolution of Edward Snowden, from extreme Libertarian (I hesitate to say even fanatic, and I don't want to say worse) to American, panpolitical hero. The interviews with Ron Paul, the ideas on the New Deal that could not have been the product of a mere "kid", the friendships with well-known Libertarian figures, and just about a thousand other things that put and added together start making a lot of sense and paint a clear, consistent picture. "The other half" of the other half, in other words. Being 'fearless' perhaps starts with those subjects that are closest to us, and that hurt us the most - this hasn't occurred in this book, nor in this newspaper affiliated with its author, and cannot occur for most obvious reasons... 
11. Wollenberg, Charles. 2008. Berkeley. University of California Press.

Description although I don't know exactly how, this book will surely be useful to people wishing to study or do research on this leading public university for computer science in the United States. Any history of a university, or research or educational institution, would be incomplete and lacking without some references to its city, district, neighborhood... (This was a major argument in Le Goff's book on the emergence of these peculiar places, built around specific, urban spaces.) Otherwise, start with the archives of the university, those of the department, and its de facto predecessors (most likely somewhere within, or in-between electrical engineering and maths) - don't forget the The Daily Californian, and perhaps the Los Angeles Times, both established shortly after the university. There would be other places to look at : clubs, laboratories, dorms, libraries, etc. (UT Austin, where Dijsktra taught for many years, would be another interesting subject.)

12. Suelette Dreyfus and Assange, Julian. 1997. Underground: Tales of Hacking, Madness and Obsession on the Electronic Frontier.

Description the beginnings of Julian Assange, among others.

13. Medina, Eden. 2011. Cybernetic Revolutionaries: Technology and Politics in Allende's Chile. MIT Press.

Description Project Cybersyn (in Chile). (I'm not sure about the perspective, or worth of this book - it's far from my own areas, but the originality if not uniqueness of its subject makes it noteworthy.)

\section{Articles}

14. JBHE. 1999. "No Need for a Calculator to Tabulate Black Computer Science Faculty at the Nation's Highest-Ranked Universities" The Journal of Blacks in Higher Education 24 : 69-71.

Description "(...) no blacks among the 550 computer science faculty at the nation's highest-ranked universities." Poor, poor, science, this computer science... It really does not understand itself. (And, I certainly did not need a calculator either - that's how little the secrets of this world are to anyone with an earnest wish, and will to understand it.)

15. Richard Bornat. 2009. "Peter Landin: a computer scientist who inspired a generation" Higher-Order and Symbolic Computation 22(4) : 295-298.

Description Peter Landin is a somewhat tragic figure within computer science (or heroic, depending on one's worldview). When he saw the uses that his discipline had, or was made to have, he gradually moved away from it... "son of an accountant father disabled in WW1", "Computing was never his entire life. He was always a radical in politics, a regular on demonstrations"...

\section{Textbooks}

"Scholars", who live as Saint Jerome in his study, will never understand the point of this section... 
16. Scott, Michael. 2016. Programming Language Pragmatics. 4th ed.. Morgan Kaufmann. ("an imprint of Elsevier")

Description The old(er) model of the PL (programming languages) textbook done in a comparative fashion; sometimes in excruciating detail (See chapter 6 for logic and comparison operators in multiple languages...). Largely based on imperative languages, the functional paradigm is treated as some sort of an after-thought in a back chapter (ch. 11). In the appendix, yet another genealogy of programming languages is found.

17. Friedman et al.. 2001. Essentials of programming languages. 2nd ed.. MIT Press.

Description the anti-thesis to Scott. Here, one language, Scheme, wellsuited for the task due to its nature as a functional language (everything is a list which can be represented as a tree?), is used to explore similar ideas around the formal aspects of programming languages, instead.

18. Touretzky, David. 1989 []. Common LISP: A gentle introduction to symbolic computation. ?

Description "Although widely known as the principal language of artificial intelligence research - one of the most advanced areas of computer science - Lisp is an excellent language for beginners. (...) The student could be from any discipline, from computer science to the humanities." writes Touretzky here. (Preaching to the choir.)

\section{Documentaries}

19. Collective. 2006. Steal this film.

Description Aaron Swartz and Peter Sunde are interviewed. A young (and still idealistic) Fred von Lohmann makes a surprise appearance. The important historian Robert Darnton tells of censorship and the "pirates" of the printing press in 18th c. Europe; leading to apt comparisons with the so-called "pirates" of our age, and their criminalization.

20. Poitras, Laura. 2016. Risk.

Description In the middle of narration, Laura Poitras admits to having slept with Applebaum. And, while this is a great moment of self-reflective documentary filmmaking, it does raise questions as to the independence of these various journalists from their subjects. "A little too close for their own good", we wrote, and more, elsewhere. This would certainly explain why the press has remained uncritical so long. (I could have also mentioned Quinn Norton and Swartz, among others; a near-bottomless task I don't have the heart to undertake myself. Groupies and side-characters galore, the same patterns as found in Rock history...)

21. Csicsery, George. 1993. $N$ is a Number: A Portrait of Paul Erdos.

Description the traveling mathematician of no home, no university affiliation, no possessions, and little ambitions; became one of the most productive (and collaborative) mathematicians of all times. Erdos' life strikes as so different from our modern computer scientists' - they have "a business on the side", we wrote of them disparagingly - that the inclusion of this documentary seemed warranted. Preceded the perhaps better known biography The Man Who Loved Only Numbers. 
22. Sykes, Christopher. 1989. Wittgenstein: A Wonderful Life. BBC.

Description Another portrait of a scientist offered as contrast to our very adroit, modern-day computer scientists - we must give them that, very adroit : they flip-flopped like their circuits. At the height of his celebrity, disappeared to work anonymously in a variety of low-profile professions. (See also the more avant-garde 1993 Wittgenstein by Derek Jarman.)

\section{Fiction films and series}

Historians don't know it yet, but this will soon become one of their many new sources. For a new history.

\section{The $X$-Files.}

Description Many prescient episodes on among others artificial intelligence and one NSA whistleblower. (S09E15 covers the death of The Lone Gunmen; they later became the subject of a series of their own, of same name.)

\section{Mr. Robot.}

Description Praised for the realism of its "hacking" scenes. Season 3 is one of the biggest sell-outs in television history. Not only couldn't they go through with the original narrative and gave up on it (i.e. crashing banks was a mistake), but they had to inject elements of supernatural (i.e. time hacking) just to be sure people wouldn't mistake any of it as something that might happen. USA Network $\rightarrow$ (owned by) $\rightarrow$ NBCUniversal $\rightarrow$ Comcast $\rightarrow$ the Roberts family dynasty. Billionaires, philantropy, Hillary Clinton, the whole package! And, as such the show came full circle, too... ("Infrastructure" and "superstructure", etc. etc..)

\section{Buffy.}

Description female lead series enjoyed by a variety of technologists and computer scientists (Aaron Swartz, Conor McBride, etc.). An evolution of computers could be written by watching this show alone, and following the changes in the equipment used by, for instance, Willow (from clunky black laptop to sleek white one of a certain brand, "designed in California [but] made in China"...).

\section{Neon Genesis Evangelion.}

Description high-tech dystopia with children fighters and regular citywide shutdowns; Christian motifs (the 3 Maggi, etc.).

27. Akmut, Camille. 2019. "The popular culture of computer scientists..."

Description a 4-part publication in which I attempted to point people in the right directions. As much included as twice not..

28. Lucas, George. 1971. THX 1138.

Description this is one film I didn't include, among a myriad of others. Android. Lucas before Star Wars. (His debut.)

29. Marker, Chris. 1997. Level Five.

Description the other, infinitely great director of French left-bank cinema (various collaborations with Resnais). Laura is a programmer... 


\section{Fiction books}

I had focused on popular rather than high culture, better traveled and covered.

30. Orwell, George. [1949]. 1984.

Description the doublespeak of technology companies, in which our language is in a constant state of re-invention, and where regressive is continuously attempted to be re-defined as progressive - sometimes very successfully so, at least temporarily. E.g. "flexibility" instead of precarity, e.g. gig economy workers are "(self-)entrepreneurs", e.g. "aggregation" not classification, and other such grotesque buffoonery; so extreme that even Orwell, who did not lack in imagination, couldn't have conceived. E.g. Ueber is not a taxi business, hence it should not be submitted to the same overview. E.g. AirBnb is not a "traditional" real estate company, hence the regulations imposed on that industry does not apply to it. E.g. Delivery Hero (gig economy applied to food deliveries), is not a "real, real" business of the "old" restaurant industry, hence... well, you know the melody. Our politicians move to the rhythms of their songs, unbeknownst to them (our recommendation to them : replace everything they say with the opposite, and you'll get the original meaning or message).

31. Huxley, Aldous. 1958. Brave New World Revisited.

Description the "real sufferers of mental illnesses" are normal people argues Huxley. (Like Sandberg, for example, who, in her folly, that is so great, conceives of herself as a "revolutionary"...).

32. Dante. The divine comedy.

Description Dante had specifically meant to describe his contemporaries. This was no "historical" novel! Today, there would have been a place in Inferno and Purgatory (the best parts of this "comedy") for all of them. (Even the people in Paradise are not without faults...)

33. Dickens, Charles. [1843] A Christmas Carol.

Description It is never a bad time to read Dickens. Tech executives are the modern Ebenezer Scrooge's... (The adaptation with Alastair Sim.)

\section{Methodology}

Gary Younge quoted historian E.C. Carr recently : "The 19th-century fetishism of facts was justified by a fetishism of documents". Independently we can add that no amount of archives ever made any history books, or historian. In the deaths of the Romanovs, some construct "a great tragedy", while others cannot help themselves and only see farmers and servants dancing and being merry together — "the (...) interests of the borrower [are not that] of the usurer" wrote Marx when he was working as journalist; but neither are those of Royal historians, old and new, and non-Royal ones, old and new. And, when Yurovsky pulled the trigger, he must have lost a big part of himself too - but none of this is something that is likely to be found in any archives.

34. Engels, Friedrich and Marx, Karl. [1844]. The Holy Family. Description complement and predecessor to The German Ideology. 
35. Marx, Karl. [1844]. Economic and Philosophic Manuscripts.

Description this is what people mean when they say "the young Marx". (It's hard to picture how such texts could have existed in the 1840's. In fact, they remained unpublished until much, much later - about a century passed before that could happen.)

36. Le Goff, Jacques. 1993. Intellectuals in the Middle Ages. Wiley-Blackwell.

Description intellectuals more often than not do not know where they come from, or what their own history is - a fact of many consequences on their lukewarm science and oh-so gentle, delicate prose... In this grand book, which has not received the reception it deserves, Le Goff guides us through "schools of the city", and "monastic" ones, and constantly pokes us and asks : 'well, how do you feel this reflects on us?' But, one must (be able to) read between the lines...

37. Zinn, Howard. A People's History of the United States.

Description a look at history from down below, also called social history. Howard Zinn had not needed much imagination to put himself inside the bodies and minds of simple folks - he had come from them. Except, now historians rarely do, and it remains a life-long mystery to them why despite their best efforts they simply couldn't do anything worthwhile. They never could. (And, thus, by default, turned to studying merely other intellectuals, the only "milieu" they ever knew, but never quite understood...).

38. Eribon, Didier. Michel Foucault.

Description the reference biography of Michel Foucault. (His friend Paul Veyne had a copy in his attic library, with dedication if I remember correctly.) (The crossdressing prostitute, who might have been transgender, was out of Hamburg and its famous Reeperbahn, with the same reservation as before.) (I saw his partner, the sociologist Daniel Defert, at a screening of Alexina...)

39. Dover, Kenneth. 1989. Greek Homosexuality. Updated and with a new postscript. Harvard University Press.

Description a landmark study that had the effect of a small bomb upon its release, unheard of was a history book on a dangerous topic such as "homosexuality", coming from such a respectable scholar... (Though, his autobiography certainly paints a different picture.) The title itself is subversive, but its effect is lost on most. Greek homos'. In any case, I have proposed that the male-exclusive culture of hackers must have lead to similar patterns as found here (i.e. not modern homosexuality, but the Pederastic kind, closer to bisexuality). (I can't prove it, and for now we must rely on Levy's account, and dominant, heterosexual vision of the world. Peanuts and in-jokes with the bros...). This should be useful to anyone wanting to write a history of computer from an LGBT perspective. 40. Foucault, Michel. History of sexuality. Vol. 2.

Description the introduction is where Michel Foucault explains his attitude towards science (his own). He wrote to change the way he thought... (Writing about computer science and technology certainly changed the way I thought, far beyond what I had originally envisioned, or planned.) 


\section{Newspapers}

\section{Reuters}

Description the journalists' newspaper. (Reading the other newspapers after Reuters is sometimes depressing, so little they add that could help us better understand current events.)

42. Motherboard (Vice)

Description useful to me in one research, where I had made use of one of their documentaries, I re-discovered it as a surprisingly critical publication; resulting in surreal events...

\section{Jacobin}

Description generalist magazine with a Socialist, Marxist sensibility. Regular articles on technology-related topics. E.g. tech companies and their worker-annihilating policies, passed as the nec plus ultra of modernism, if not revolutionary in nature...

\section{Misc.}

The other 6 or 7 references are found in Bob Dylan and Nina Simone songs, for example, like the "Ballad of the Hollis Brown"... And, in life. 